\title{
Deegoizacja jako cel wychowania - paradygmat duszy
}

\begin{abstract}
Abstrakt
Artykuł traktuje o człowieku jako istocie funkcjonującej w porządku wyobrażonym i zdolnej do tworzenia obrazów. Jednym z tych obrazów jest konstrukt ego przedstawiony w perspektywie psychologii krytycznej Kurta Danzigera oraz psychologii imaginalnej/paradygmat duszy (soul movement) Jamesa Hillmana. Autorzy wprowadzają te dwa podejścia celem zasygnalizowania obszaru badawczego, który potencjalnie może być wykorzystany we współczesnej refleksji nad kategorią wychowania. Analiza krytyczna wskazuje na swoistą redukcję natury ludzkiej i historii człowieka we współczesnej psychologii do historii „ja” i dominacji „ego”. Natomiast koncepcję Hillmana charakteryzuje misja deegoizacji, a więc pozbawienia siły tego fikcyjnego konstruktu, na rzecz realnie istniejącej duszy, która nie tylko ma wymiar przekraczający ego, bo zawiera w sobie wielość innych obrazów, ale także osobowość, a nawet osobę ludzką. Hillman uznaje bowiem za Platonem istnienie anima mundi, czyli ensouled world, która jest szersza i pierwotna wobec nie tylko ego, ale i duszy ludzkiej, a której owa dusza jest składową. Zgodnie $\mathrm{z}$ tą perspektywą, w procesie wychowania rolą rodzica i nauczyciela staje się deegoizacja jako warunek stwarzania duszy dziecka (soul-making).
\end{abstract}

Słowa kluczowe: deegoizacja, perspektywa duszy, wychowanie, Kurt Danziger, James Hillman.

\footnotetext{
* Uniwersytet Kardynała Stefana Wyszyńskiego w Warszawie.

** Fundacja Arbor Mundi.

Artykuł otrzymano: 21.11.2020; akceptacja: 16.03.2021.
} 


\title{
Deegoization as the Aim of Education - the Soul Paradigm
}

\begin{abstract}
The article focuses on man understood as a being that exists in the imaginary order and displays the ability to create images. One of the these images is the ego construct which will be revisioned in the perspective of the critical psychology of Kurt Danziger and the imaginal psychology/soul paradigm (soul movement) of James Hillman. The critical analysis points out a specific reduction of human nature and human history in contemporary psychology to the history of "self" and domination of "ego". The conception of Hillman, by contrast, is characterized by the mission for deegoization, therefore strips the power away from this fictitious concept in favor of a realistically existing soul which not only can exceed the ego, but also a personality, or even the whole human being because it contains a variety of images. Hillman believes, following Plato, in the existence of anima mundi, an ensouled world, which is wide and more primal than the ego, but also a human soul, because the soul is a part of it. In accordance with this perspective, the role of a parent and teacher in the process of education is deegoization as a condition for the soul-making of a child.
\end{abstract}

Keywords: deegoization, soul perspective, education, Kurt Danziger, James Hillman.

„Terapia idei mogłaby uwolnić nas od owych konwencji, które utrzymują nasz umysł w ryzach, powstrzymując go przed dokonywaniem interesujących transgresji".

James Hillman 2017: 22

\section{Wprowadzenie}

Przedmiotem rozprawy jest wstępna analiza dominującej obecności i znaczącego wpływu konstruktu ego na pojmowanie natury ludzkiej we współczesnej psychologii oraz refleksja nad znaczeniem tego podejścia dla okresu dzieciństwa i kategorii wychowania w ujęciu psychologii imaginalnej Jamesa Hillmana. Nasze rozważania rozpoczniemy od naszkicowania kontekstu antropologicznego, z którego wyłoni się człowiek funkcjonujący w porządku wyobrażonym i zdolny do tworzenia obrazów pochodzących z duszy. Jednym z tych obrazów jest konstrukt ego, którego specyfika i zasięg oddziaływania będzie poddany analizie przy pomocy krytycznej rewizji (critical review), inspirując się twórczością wszechstronnego, wnikliwego i „marginalnego" (jak sam o sobie pisał) badacza i historyka myśli psychologicznej Kurta Danzigera oraz podążając wybranymi ścieżkami psychologii krytycznej ${ }^{1}$. Następnie

\footnotetext{
1 Myślenie krytyczne w psychologii ma swoją długą tradycję, sięgającą korzeniami do pism Wilhelma Diltheya $(1982,1987,2004)$, który dokonał podziału na nauki rozumiejące (historyczno-kulturowe) i wyjaśniające (przyrodnicze) oraz zaproponował program psychologii jako nauki deskryptywno-
} 
wprowadzimy paradygmat duszy (z reguły rozumianej jako perspektywa, ale czasem/opacznie traktowanej substancjalnie) Hillmana i jego zalecenia, co z ego czynić należy, aby zrobić centralne miejsce dla duszy. Zakończymy nasze rozważania, wskazując na wartość tego myślenia dla pojmowania dzieciństwa i kategorii wychowania - rozumianego jako towarzyszenie dziecku w ujawnianiu jego duszy 2 . Całość tekstu, ze względu na rozległość (a także wieloznaczność i liczne niekonsekwencje) myśli Hillmana oraz wielowymiarowość i długą historię badań konstruktu ego, a także idei wychowania, stanowi jedynie przyczynek do dalszej, pogłębionej analizy, której wymaga również wielowątkowa myśl wybitnego metodologa i historyka psychologii - Danzigera. Tekst można zatem traktować jako wyłącznie wprowadzenie w polski obieg naukowy myśli obu uczonych zrelatywizowanej do relacji ego - wychowanie.

\section{Kontekst antropologiczny}

Porządek homo sapiens, choć zakorzeniony jest we względnie stabilnym porządku materialnym, inaczej świecie naturalnym, posiada dwie znaczące cechy: ma charakter wspólnotowy/intersubiektywny oraz wyobrażony. Ten ostatni rządzi naszym życiem i kształtuje nasze pragnienia, chociaż (bowiem?) jest wyłącznie zmyślony. Rewolucja poznawcza homo sapiens to właśnie czas budowy fikcji realizowanych poprzez inwencję i współpracę: wyobrażeń, legend, mitów, bogów - znaczących historii, a wraz z nimi kultury jako hipotetycznych czy kontrfaktycznych obrazów. Sukces demograficzny i cywilizacyjny człowieka, jako niegdyś mało znaczącego zwierzęcia i niezbyt sprawnej (długi rozwój osobniczy, niewielka specjalizacja etc.) małpy, homo sapiens zawdzięcza właśnie dwóm „W”: wyobraźni (duży mózg, a w nim silnie rozwinięte płaty przedczołowe, w efekcie narzędzia, zdolność uczenia się, planowanie, plastyczność etc.) i wspólnocie, a w jej ramach współpracy wspólnotowej przekraczającej 150 jednostek (Dunbar 2019).

Konstrukty kulturotwórcze kształtujące i podtrzymujące porządek społeczny to zatem „tylko" dla przykładu... irracjonalne mity? Wydaje się, że w oparciu o cytowaną literaturę przedmiotu można postawić $\mathrm{w}$ tym tekście taką tezę: my = ludzie prawdziwie wierzymy $\mathrm{w}$ mity, które wyłącznie (sic!) istnieją $\mathrm{w}$ zbiorowej wyobraźni lub osób znaczących, ale opiniotwórczych. Są silniejsze niż przypusz-

-analitycznej. Późniejsze tradycje myśli krytycznej mają swe źródła w psychoanalizie, psychologii humanistycznej, psychologii feministycznej i postkolonialnej. Interesujący projekt wyłania się z rozważań w ramach psychologii krytycznej (critical psychology). Zdaniem Iana Parkera (1999) psychologia krytyczna narodziła się z wielu krytycznych perspektyw teoretycznych. Uważa on, iż zadaniem psychologii krytycznej jest poddawanie systematycznej rewizji uprzywilejowanych obszarów wiedzy psychologicznej oraz badanie założeń ontologiczno-epistemologiczno-etycznych i ideologicznego zaplecza dominującego paradygmatu w psychologii.

2 Podejście Hillmana można zestawić na gruncie polskim z ideą samowychowania Janusza Korczaka, przesłaniem „nowego wychowania” rosyjskiego pedagoga Konstantina Wentcela czy myślą amerykańskiego filozofa Johna Deweya i włoskiej lekarki Marii Montessori. 
czamy, bowiem mogą odpowiadać nawet za rozluźnienie symbiozy z naturą. To, co nas homo sapiens zdecydowanie różni od najbliższego krewnego - szympansa bonobo (a nie jest to większość zachowań społecznych, empatia, neurony lustrzane, elementy moralności, a nawet materiał genetyczny, bo różni nas jedynie... 1,24\% DNA! - De Waal 2018), innych człowiekowatych, a tym bardziej szerzej - człekokształtnych i naczelnych to owo „mityczne spoidło” (Harari 2018: 51), czyli współoddziaływanie znaczących idei, obrazów i wyobrażeń wiążące wielką liczbę ludzi. Ten fikcjotwórczy styl funkcjonowania umysłowego, wyrażany w języku homo sapiens, pozwala na wspólne i poprzez wspólnoty wyobrażone (lub osobowe, ale przekazywane w celu współdziałania) tworzenie alternatywnych światów, w tym silnych konstruktów kulturo- i tożsamościotwórczych. Wydaje się zatem, iż człowiek jest istotą, która, prócz źródeł życia pochodzących z rzeczywistości materialnej, takich jak tlen, pokarm czy woda, karmi się/odżywia równie intensywnie i bezwarunkowo rzeczywistością wyobrażoną - symboliczną, semantyczną, szeroko ujmując kulturowo-religijną. Nie żyjemy nago w przyrodzie, ale także (nie dodatkowo, lecz równolegle) w uniwersum symboli, wspólnych mitów i prywatnych fantazmatów. Porządki wyobrażone determinujące nasze życie to nie tylko te oczywiste, jak pismo, liczby, wyznania, ale także nauka, systemy społeczno-polityczne, światopoglądy, a nawet korporacje i ich marki, pieniądz czy model/idealizacja, a więc wyobrażenie miłości romantycznej.

Jednym z prekursorów w psychologii wyłożonej powyżej myśli antropologicznej jest uczony określany mianem Williama Jamesa XX w. - nomen omen James Hillman. Jego myśl nazywana bywa psychologią imaginalną oraz wpisywana jest w tzw. soul-movement i paradygmat wyobraźni. Silnym wyróżnikiem człowieka w stosunku do świata zwierząt, według Hillmana, jest zdolność do tworzenia obrazów, których krynicą jest dusza ludzka. W jej ramach, duszy rozumianej jako miriady obrazów i perspektywa raczej niż byt czy substancja, jednym z wielu obrazów, ale będącym silnym konstruktem od początku czasów nowożytnych, a szczególnie od czasów Kartezjusza, dalej rewolucji naukowej i przemysłowej, jest w obszarze euroamerykańskim kultury zachodniej, w tym w psychologii, konstrukt ego (Hillman 2016, 2000). Emancypacja jednostki, a nawet w ogóle kariera samej idei jednostki to efekt splotu wielu czynników: od renesansowego humanizmu i zainteresowania człowiekiem (także innym od Europejczyka - okres wypraw odkrywczych), a dużo wcześniej antyczne gnothi seauton (poznaj samego siebie), poprzez oświeceniową estymę, jaką zaczęto obdarzać rozum jednostki, warunek jej istnienia/tożsamości (cogito ergo sum) i kult rozwoju i kariera idei ewolucji (Karol Darwin), po ideę postępu i rewolucję przemysłową oraz etykę kapitalizmu (bogacenie się jednostki jako źródło bogacenia się ogółu, egoizm = altruizm, konsumpcjonizm = napędzanie gospodarki/dobrobytu).

Konstrukt ego zrobił między innymi z powyższych (ale i innych, o których traktuje ten tekst) powodów także niebywałą karierę w psychologii, młodej nowożytnej nauce powstałej u końca XIX w. Ta fascynująca dyscyplina powstała w Europie, 
kręgu niemieckojęzycznym, szybko zdobywając zainteresowanie kultury frankofońskiej i anglosaskiej, niektórzy podkreślają też jej protestanckie umocowanie (WASPS - White Anglo-Saxon Protestants). Hillman traktuje konstrukt ego jako „przeinwestowany”/przeszacowany w koncepcjach psychologicznych i psychoterapeutycznych, a przez to szkodliwy i uniemożliwiający zrozumienie ludzkiej duszy. W większości swych tekstów robi wszystko, by go deliteralizować, adekwatnie metaforyzować i w efekcie zrzucić z piedestału. Uznaje ego jako jeden z wielu mało znaczących obrazów duszy, który jednak intruzywnie, by nie rzec inwazyjnie zalał nowożytną kulturę zachodnią, w tym myśl psychologiczną, rozjaśniając niewielki wycinek pokoju duszy, zaciemniając tym samym znaczącą resztę jej przestrzeni. Szkodliwość kultu ego w kulturze zachodniej podkreśla poprzez błędne podejście obecne w psychoterapii, w której, choć jak pisze, mamy ponad 100 lat tradycji psychologii ego, a jednak świat idzie ku gorszemu. On sam po 40 latach efektywnej praktyki terapeutycznej zdecydował się porzucić leczenie ludzi na rzecz leczenia chorych idei w psychologii, w tym na rzecz jej „deegoizacji”.

Hillman jest wyłącznie badaczem silnie ugruntowanym w myśli platońskiej (m.in. Plotyn, Proklos, Ficino) i absolutnie nie ma ambicji budowania systemu duchowości, ale deegoizacyjny sposób myślenia, który uprawia na gruncie psychologii i psychoterapii, a szerzej humanistyki, ma głębokie podwaliny w tradycjach duchowych wielu rejonów świata. Weźmy dla przykładu dwa skrajne analogi: wschodni buddyzm zen i zachodnią mistykę nadreńską. W obu tradycjach, pomimo iż wywodzących się z zupełnie z innych kultur, czasów i religii, a szerzej światopoglądów, a więc mających zdecydowanie odmienną proweniencję metafizyczną i aksjologiczną, spotykamy się z podobnym i silnie ugruntowanym przekonaniem o konieczności niwelowania ego na drodze rozwoju duchowego. Nie jest ważne, czy jest to radykalnie brzmiące zabicie ego, by dojść do oświecenia w kulturze wschodu, czy też ogołocenie się, czy inaczej opróżnienie z ego, by umożliwić bezpośrednie spotkanie/wlanie się Boga w człowieka według średniowiecznych mistyków niemieckich (nomen omen „mistyka wlana”), zmagania dotyczą, czy wręcz dotykają, kwestii silnego, przeszkadzającego w spotkaniu $\mathrm{z}$ transcendensem konstruktu umysłowego, który Frankfurtczyk w Teologii niemieckiej nazywa mojością/sobnością (Frankfurtczyk 2013).

\section{Ujęcie krytyczne}

Rozpocznijmy naszą krytyczną rewizję od refleksji, iż psychologia poszukuje nowej wiedzy o zjawiskach, które zazwyczaj istnieją w języku potocznym, mają swoją historię i zostały ukształtowane często w długim oraz złożonym procesie społecznego tworzenia wiedzy. Dziedzictwo przeszłości w różnym stopniu wpływa na pojęcia, którymi zajmuje się psychologia. Historia pojęć przebiega często w przery- 
wanym i burzliwym stylu oraz ma wiele ścieżek rozwoju. Znaczenie owych pojęć jest integralnie związane z praktyką społeczną i ściśle wynika oraz współtworzy prawne, religijne, medyczne czy naukowe instytucje. Niektóre z psychologicznych kategorii są wytworem XX w. (dla przykładu, testy inteligencji czy PTSD), inne natomiast są konceptualizowane i stosowane od dawna (dla przykładu, osoba czy pamięć). Pojęcie osoby $\mathrm{w}$ samej psychologii zostało zdefiniowane stosunkowo późno, w porównaniu z jego długą tradycją, i niezwykle szybko zostało zastąpione alternatywnymi i redukującymi je pojęciami. Danziger posuwa się nawet o krok dalej, stwierdzając, iż pojęcie to zostało głęboko nadużyte (a thoroughly abused concept) (Danziger 2012: 59). Jednakże większość psychologów zignorowała ten problem i kontynuowała empiryczne badania, nie zadając sobie pytań o przedzałożenia swych interpretacji, publikując obiektywną wykładnię na temat natury ludzkiej, w której nie było miejsca dla implicytnie odrzuconych kategorii, takich jak dusza nieśmiertelna czy charakter moralny. Jak tylko dyscyplina psychologii osobowości została utworzona (Gordon Allport), zapanowała swoista „amnezja historyczna" (Danziger: 60), która spowodowała, iż wiele istotnych kwestii usunięto z pola namysłu, a linia oddzielająca nowy obszar wyraźnie i jednoznacznie zarysowała granice prawomyślności. W pewnym momencie historia osoby praktycznie zniknęła, a pojawiła się historia „ja” (self) i konstrukt ego. Zdaniem Danzigera, „powszechne stało się rozprawianie o cechach osobowych, które wcześniejsze pokolenia uznałyby za niestosowne, zawstydzające lub niegodne” (tamże: 80).

Gdzie należy szukać źródeł tej amnezji historycznej i mocnej pozycji konstruktu ego? Korzystając z przemyśleń psychologii krytycznej, można stwierdzić, iż wielu psychologów nieświadomych jest swego stanowiska teoriopoznawczego i broni się przed ujawnieniem ideologicznego zaplecza, uznając siebie za obiektywnych naukowców (value-free scientists), opisujących rzeczywistości per se (Sloan 2009: 62). Wybór określonego paradygmatu i jego dominująca pozycja implicytnie wspiera model społeczeństwa, który usprawiedliwia status quo i decyduje o przeznaczeniu osób w nim funkcjonujących. Ponadto promuje pewien schemat rozwoju człowieka, a w związku z nim określa jego znaczenie, potrzeby i funkcje. Co więcej, psychologia nasycona jest językiem pochodzącym z biomedycznego modelu ludzkiego cierpienia i pomija doświadczenie cierpiącego człowieka oraz złożony kontekst społeczno-kulturowy33. Natomiast powszechnie używane i promowane kategorie normy czy patologii mocno związane są z etnocentrycznymi wartościami, zwyczajami i normami białych reprezentantów klasy średniej ze Stanów Zjedno-

\footnotetext{
3 Ciekawym przykładem jest PTSD (post-traumatic stress disorder), kategoria, która została stworzona dla weteranów wojny w Wietnamie cierpiących z powodu bycia sprawcą i świadkiem niewyobrażalnego okrucieństwa. Jednakże, w niedługim czasie badacze zainteresowali się prawdopodobieństwem zapowiedzi PTSD w dzieciństwie, neurologicznym lub genetycznym podłożem PTSD czy lokalizacją miejsca odpowiedzialnego za PTSD w mózgu, kompletnie odsuwając niewygodną prawdę związaną z moralnymi konsekwencjami wojny i cierpieniem ludzkiego sumienia (Marecek, Hare-Mustin 2009: 80).
} 
czonych Ameryki Północnej ${ }^{4}$. Służą one do kolonizacji mniej wpływowych grup społecznych i obszarów świata poprzez implementację dominującego paradygmatu, a tym samym przyczyniają się do posługiwania się nieadekwatną wiedzą i praktyką psychologiczną, które deprecjonują treści ujawniane w odmiennej i lokalnej psychiczności (Pankalla, Kilian 2018). To ogromne i długo zaniedbywane terytorium życia psychicznego powoli zostaje objęte refleksją naukową również przez psychologię indygeniczną, która opierając się na dziedzictwie psychologii historyczno-kulturowej oraz psychologii krytycznej, przedmiotem swych badań uczyniła lokalnie tworzoną wiedzę na temat ludzkiej psychiczności5 ${ }^{5}$.

\section{Dusza a ego}

Na innych peryferiach myśli psychologicznej Hillman reaktywował paradygmat duszy w ramach rozwijanej przez niego psychologii imaginalnej (zwanej też archetypową), która wyrastała z twórczości Carla Gustava Junga i jednocześnie konstruktywnie ją krytykowała. Ta niezwykle oryginalna koncepcja skupiała się na podstawowych wzorcach tzw. archai pochodzących z wyobraźni i rządzących życiem psychicznym, które są obecne w kulturze i szeroko rozumianej aktywności ludzkiej. Wzorce te mają charakter fenomenów, ale i transcendują empiryczną rzeczywistość czasu i przestrzeni, a wyrażają się poprzez mit rozumiany jako podstawowy wzorzec ludzkiego myślenia i egzystencji.

Zgodnie z założeniami psychologii archetypalnej Hillmana, człowiek jest jedyną metaforą człowieczeństwa, a psychologia jest nauką o duszy. Hillman rozumie duszę, za Arystotelesem, jako zasadę i formę dla ciała, która kształtuje ciało i kieruje nim. Dusza nie ma natury substancjalnej, lecz jest perspektywą i procesem, podczas którego dokonuje się zamiana wrażeń w przeżycia i doświadczenia. Ma ona szczególną relację z patologią i ze śmiercią, a najpełniej wyraża się poprzez miłość. Jej unikalna rola polega na badaniu swoiście ludzkich, intymnych i subiektywnych mikrodoświadczeń osobowych, tworzonych w danym kontekście historyczno-kulturowym i w odniesieniu do Absolutu. Zdaniem Hillmana,

\footnotetext{
${ }^{4}$ Adrian Brock opisał trzy zasady, zgodnie z którymi odbywa się włączanie jednych a wykluczanie innych treści z historii psychologii: 1) nie uwzględnia się badań i stanowisk teoriopoznawczych, które nie miały znaczącego wpływu na psychologię amerykańską, nawet jeśli wywarły silny wpływ lokalny; 2) ważną częścią historii psychologii jest dorobek naukowy, który miał znaczący wpływ na psychologię amerykańską, pomimo że jest nieadekwatny w innych obszarach świata; 3) Azja, Afryka, Ameryka Łacińska i Oceania „w psychologicznym świecie nie istnieją” (Brock 2006).

5 Amerykański antropolog Clifford Geertz stworzył podstawy dla rozwoju perspektywy indygenicznej w psychologii. Geertz (2005) zakładał niemożność obiektywnego poznania i pełnego zrozumienia badanej kultury oraz fragmentaryczność wiedzy będące efektem etnocentrycznego obciążenia badacza. W związku z powyższym postulował budowanie „wiedzy lokalnej”, która powinna dominować i być tworzona w oparciu o przekonania i doświadczenia badanych osób.
} 
prawdziwe zrozumienie natury ludzkiej musi się zaczynać od duszy oraz wykorzystywać metody, które są najbardziej odpowiednie do zgłębiania głównego przedmiotu badań psychologicznych, jakim jest psyche. Psychologia znaczy przecież „logos psyche”, a więc „mowa” czy też „słowo, opowieść duszy" (ang. telling of the soul). (...) A logiką psychologii jest z konieczności metoda rozumienia, która opowiada o duszy oraz przemawia do duszy jej własnym językiem (Hillman 2020: 72).

To właśnie takie podejście, zakładające pogłębione wnikanie w przesłanie wewnętrznych znaczeń sprawia, że psychologia staje się coraz bardziej naukowa.

Większość badaczy ma swój ulubiony przedmiot badań, lejtmotyw, ale także przeciwny punkt odniesienia, antywartość, w stosunku do której, a dokładniej w opozycji wobec której, konstruuje często swą perspektywę. Gdyby szukać takiej idei, której zwyczajnie Hillman nie lubi, a także w której upatruje przyczynę wielu kłopotów człowieka i współczesnej kultury, w tym porażek psychoterapii, to na pewno byłby to konstrukt ego. Według niego to zmora naszej, czyli współczesnej, a szerzej zachodniej, kultury od czasów Kartezjusza, która zamiast mieć swe miejsce w szeregu jako jeden z mniej znaczących obrazów, stała się przedmiotem kultu. Hillman proponuje po pierwsze desubstancjację ego, dalej jego relatywizację, a przede wszystkim detronizację tej chorobotwórczej idei, z której, jak buddyści, chce nas wyleczyć. Przypomnijmy, iż po 40 latach zarzucił psychoterapię, leczenie chorych ludzi na rzecz, jak mówi, leczenia chorych idei w psychologii i kulturze, do których jego zdaniem na pewno należy ego - centralne/decydujące miejsce tego obrazu wśród innych i w kulturze i psychologii i psychoterapii i co najgorsze, w naszych przekonaniach i postawach. Jego koncepcję charakteryzuje misja deegoizacji, a więc pozbawienia siły tego fikcyjnego konstruktu, na rzecz realnie istniejącej (perspektywy) duszy, która nie tylko ma wymiar przekraczający ego, bo zawiera/pozwala czuć w sobie miriady innych obrazów, ale także osobowość, a nawet człowieka. Hillman zakłada istnienie anima mundi, czyli ensouled world, która jest szersza i pierwotna wobec nie tylko ego, ale i duszy ludzkiej, a której nasza dusza jest składową. Taka transcendenta, u swych źródeł antyczna, a po części parareligijna i antyegocentryczna perspektywa, zawiera wartość pokory, siły przeznaczenia, poddania się rzeczywistości Boga...

Dla Hillmana ego jest wyłącznie jednym z kompleksów w psyche, o dużej sile w naszej kulturze, a psyche jest policentryczna/polifoniczna/politeistyczna... Ego to jedynie nikły promień rozświetlający niewielki obszar duszy - rzeczywistości psychicznej, a w efekcie oślepiający jej właściciela i zaciemniający całą dostępną przestrzeń/realne doświadczenia duszy. Hillman dokonał redefinicji umiejscowienia i istotności pojęcia ego, które w jego teorii przestało być centralnym rdzeniem psyche, ale tylko jednym z wielu zamieszkujących ją obrazów. Paradoksalnie, w jego opinii, silne ego (odpowiedzialne za mechanizm racjonalizacji) jest jedynie przeszkodą dla kontaktu z obrazami, za pomocą których kontaktuje się z nami dusza. 
Hillman buduje podwaliny pod teorię osobowości, która jest transpersonalna i antyegocentryczna. Jej założenia to: skupienie na procesach przeciw ego, obcych ego, poza ego, spersonalizowanych figurach doświadczenia obiektywnego/mitycznego; podejście transpersonalne, polifonia i poliwalencja osobowości politeistycznej (w psychologii głównego nurtu powszechna jest monoteistyczna teoria osobowości jako efekt tradycji chrześcijańskiej, kultu ego i jaźni, a osobowość wieloraka lub mnoga utożsamiana jest $\mathrm{z}$ patologią); rozszerzenie idei personifikacji treści psyche u Junga (anima, cień etc.) nie do kilku, ale do niezliczonej ilości postaci, które pozwalają ujarzmić treści psyche, nazwać je, wkomponować w siebie, doświadczyć jako osoby, głosy etc. Kolejna cecha teorii to uświadamianie sobie parcjalnych treści psyche $\mathrm{w}$ postaci częściowych osobowości oraz akceptowanie figur spoza ego w ramach danej osoby, aby rozpuścić i osłabić kontrolę ego, a ten konstrukt zrelatywizować. Ta teoria neguje rozwój osobowości czy spełnianie ról społecznych jako kluczowe dla normy, jej równowagę etc., a faworyzuje idee osobowości jako żywego, zaludnionego postaciami dramatu, w którym podmiot osobowy bierze udział, ale nie jako kluczowy, kierowniczy czy jako autor doświadczeń, ale jedna z postaci tego dramatu życia. Zdrowa czy dojrzała osobowość tu nie gra podstawowej roli, raczej ironia, humor, współczucie, kreatywność, zdolność bycia wielorakim, czyli imaginowanie i stwarzanie duszy jest kluczowe.

\section{Deegoizacja wychowania}

Jakie znaczenie ma owa perspektywa dla rozumienia pojęcia rozwoju i procesu wychowania dzieci przez rodziców oraz inne osoby znaczące? Hillman sprzeciwia się indywiduacji i wspinaniu się na kolejne szczeble rozwoju celem osiągnięcia jaźni. Jest on zwolennikiem jakościowego ujęcia złożoności, różnorodności i wielości w człowieku oraz nierozwojowego modelu bycia ukierunkowanego na stwarzanie duszy. Rozumie on przez to proces integrowania wewnętrznych obrazów, wchodzenia z nimi w introspekcyjny kontakt. Dusza zatem umożliwia nam spotkanie z obrazem na przestrzeni archetypowej, jako i że przez nas przemawiają siły mityczne. Idąc tą ścieżką, wychowanie nie jest wspieraniem dziecka w osiąganiu kolejnych etapów rozwojowych, lecz towarzyszeniem jemu w ujawnianiu treści swojej własnej duszy...

Zastanówmy się, dlaczego rozpoczynamy nasze życie jako dzieci? Odpowiadając na powyższe pytanie, możemy przyjąć perspektywę biologiczną, która dostarcza szeregu wyjaśnień służących następnie psychologii w tworzeniu swej własnej perspektywy teoriopoznawczej. Możemy jednak założyć, iż realność życia (w tym życia psychicznego) poprzedza wszelkie interpretacje o naturze człowieka, a dzieciństwo jest zamierzone przez duszę. Zatem, jeżeli idea duszy jest nadrzędną wartością wobec innych wartości, tym samym przede wszystkim musimy odkryć w dzieciństwie duszę, poprzedzając spojrzeniem z perspektywy duszy namysł nad biologiczną formą ludzkiej egzystencji. 
Życie przebiega w charakterystycznym dla siebie rytmie, a usytuowanie dzieciństwa w owym rytmie sprawia, że rozpoczyna się ono wraz z początkiem życia i kończy wraz z osiągnięciem dorosłości. Jeżeli każde dzieciństwo prowadzi do dorosłości, czy oznacza to, że głównym celem dzieciństwa jest osiągnięcie dorosłości? Idąc dalej, czy przebieg dzieciństwa powinien jawić się jako proces zmierzający ku większej racjonalności, samodzielności, produktywności, z którymi utożsamiana jest dorosłość? Paradoksalnie, dzięki owym klarownie sformułowanym celom sens dzieciństwa jest niezwykle łatwo i niebezpiecznie szybko określić. Spoglądając w głąb, można pokusić się o stwierdzenie, iż podobnie, jak próbujemy we współczesnej kulturze uwolnić się od starości, tak samo próbujemy pozbyć się dzieciństwa poprzez rozsadzanie i przesuwanie granic dorosłości przy pomocy konstruktu ego, a tym samym przyczyniamy się do powstawania szeregu bolączek i chorób psychicznych (np. plagi dziecięcej depresji), w których może odnaleźć się i zamieszkać dusza ludzka.

W jaki zatem sposób dusza ujawnia swe treści i domaga się uznania od najmłodszych lat życia? Umożliwia to charakter, który jest naszym losem/przeznaczeniem. Ani natura, ani kultura (tzw. dylemat nature or nurture), nie sofizmat rodzicielski, nie przyczynowość czy warunki środowiskowe, czy nawet kulturowe, ale nasiono/powołanie (the calling), a szerzej przeznaczenie indywidualnej duszy jako elementu duszy świata jest charakterem, czyli energią życia danej osoby. Charakter jest tu rozumiany jako swego rodzaju esencja, zindywidualizowany obraz duszy, który ma swój odpowiednik i jest psychologicznym rozwinięciem myśli klasycznych filozofów, takich jak Platon czy Sokrates. Hillman (2014) uważa, iż koncepcje stawiające na „odgrywanie scenariusza genetycznego” stawiają człowieka na miejscu ofiary i są przykładem psychologicznego redukcjonizmu. Wprowadza on metaforyczną teorię „żołędzia”, która ma pomóc akademickiej psychologii zrzucić tę presję i skierować uwagę na inne, jak dotąd niedostrzegane aspekty. Teoria ta zakłada, że charakter człowieka rozbudowuje się od pewnego jądra - metaforycznego żołędzia, który zawiera w sobie nasienie z zapisanym całym planem i strukturą dojrzałego już dębu. Ów żołądź to wypadkowa nie tylko czynników biologicznych i środowiskowych, których nie sposób wykluczyć z teorii akademickich, lecz także pewien indywidualny „los”, który ma się manifestować poprzez te czynniki i organizować je w pewien całościowy obraz. Nie dajmy się jednak zwieść mitologicznym narracjom - hillmanowskie „przeznaczenie” jest pewną funkcją naszej nieświadomości. Jest pewnym archetypem czy też narracją będącą - nie zapominajmy! - jedną z wielu alternatywnych obrazów psyche. Zatem, w myśl Kodu duszy (Hillman 2014), każdy z nas rodzi się ze ściśle określonym obrazem siebie, który definiuje nasze istnienie. Każdy ucieleśnia własną ideę, która „nie lubi być pomijana” - jakby była ona obdarzona świadomością, wolą i przyczynowością. Hillman zatem „przyznaje realność wezwaniu przeznaczenia” jako pewnej opowieści na temat duszy, której realność wcale nie musi być kluczową cechą. Hillman (2014) opisywał tę konstrukcję jako analogiczną wobec ontologii kabalistycznego drzewa życia, gdzie od symbolicznego świata pozawerbalnych pra- 
obrazów „wrastamy w dół”, jak określił to Hillman, aż do świata czysto materialnego, czyli bytu fizycznego, który jest przedstawiany wyłącznie jako pewien aspekt życia psychicznego (znów jest to obraz pierwotnej nieświadomości i wyłaniającej się zeń świadomości). Taki sposób myślenia nawiązuje do symbolicznej kabalistycznej interpretacji biblijnej przypowieści, w której Bóg (pamiętajmy, że u Hillmana jest On pewną funkcją czy nawet stanem umysłu) swoje dzieło rozpoczyna od uznania nicości za aspekt nieskończoności. Owa para przeciwieństw, czyli pierwotny dualizm umożliwiają jakąkolwiek manifestację (byt jako przeciwieństwo niebytu), a dzieło swe dopiero wieńczy człowiekiem, swoistym mikrokosmosem swego dzieła, działającym na podobnych prawach jak makrokosmos.

Novum koncepcji Hillmana polega także na nadaniu nieświadomości pewnej ewolucyjnej, dynamicznej funkcji, czyli „pierwotnego”, klasycznego znaczenia, jaki zawierał w sobie mit dajmona, czyli „ducha opiekuńczego”. Jak pisze, dusza wyobrażana jest jako biologiczny potomek dusz rodziców w taki sam sposób, jak nasza cielesność pochodzi od ich cielesności. Jednakże jest on zdania, że nie „wyrastamy z naszych rodziców” psychicznie; wręcz przeciwnie: Hillman twierdzi, że rodzina to „rodzaj fantazji i iluzji” opartej na błędnych przekonaniach. Zamiast tego dowodzi, „to nie nasza matka «dzierży władzę» nad naszym dorosłym życiem, lecz ideologia” (Hillman 2014: 132), która determinuje naszą egzystencję - wpaja nam, że to rodzice są przyczyną naszego losu, a nasze przeznaczenie (czy też charakter) zostaje zdeterminowane w pierwszych tygodniach po urodzeniu. W hillmanowskiej mitologii traktowanej literalnie (czyli z zasady błędnie!) to „dajmon dokonuje wyboru zarówno komórki jajowej, jak i plemnika, a także «dawców» zwanych «rodzicami»" (tamże). Wśród przedstawicieli dominującego paradygmatu w psychologii słowa Hillmana, nawet potraktowane metaforycznie, są bezsprzecznie niemożliwe do zaakceptowania. Jednak nie chodzi tu o krzewienie kultu naukowości - centrum zainteresowania opowieści, jaką proponuje Hillman, jest dusza. Teoria żołędzia jest zatem przykładem narracji oddającej hołd człowiekowi, pojmowanemu jako niezgłębiona kraina zamieszkała przez archetypowe byty, dajmony i obrazy. Hillman niemalże całkowicie odrzucił psychoanalityczny mit, tak zwany sofizmat rodzicielski, w którym to nasi rodzicie tworzą naszą patologię, a pierwsze doświadczenia dziecięce nieodwracalnie wpływają na nasze dorosłe funkcjonowanie. Wszystko, czego potrzebujemy, jest już w nas, rozwój, który przebiega w trakcie życia, jest metaforycznym dębem, którego struktura zapisana jest w malutkim żołędziu.

\section{Myśli końcowe}

We współczesnym społeczeństwie obserwujemy powszechny „brak zaufania”, który przyczynia się do tego, iż metafory silnego „ego" i samorozwoju mają wyjątkową moc. Ponadto „w związku ze współczesnym oderwaniem jednostkowego życia ludzkiego od norm etycznych i traktowaniem aksjologii jako reliktu przeszło- 
ści znika zainteresowanie wychowaniem do czegoś więcej niż doczesność" (Doda-Wyszyńska 2020: 251). W związku z powyższym, autorzy artykułu inicjują dyskusję na temat pojęć istniejących na peryferiach psychologii, przy pomocy których warto rozważyć miejsce dziecka w świecie i kategorię wychowania. Na gruncie psychologii krytycznej oraz psychologii imaginalnej wyłania się złożony obraz osoby ludzkiej, która przekracza kategorię ego i doświadcza swej pełni oraz łączy się ze światem poprzez perspektywę duszy.

Współczesna kultura i dominujące przekonania na temat procesu życia przesiąknięte są dążeniem do skrajnego indywidualizmu, z którego między innymi pochodzi zaniedbywanie reszty świata. $W$ jakim kierunku podążą nasze myśli, gdy za Hillmanem zdefiniujemy „ja” jako „interioryzację wspólnoty”? Zobaczmy, że indywidualna dusza odnosi się do duszy świata i znaczna jej część przebywa „poza”, na zewnątrz osoby. Jeżeli osoba ludzka jest pochłonięta przez ego, to dusza reaguje obrazami ze strefy cienia, aby zasygnalizować swe przeznaczenie i pragnienie połączenia się z duszą świata. Od początku istnienia dusza dziecka jest zaproszona do uczestnictwa w życiu świata, jednakże z uwagi na tak powszechne obecnie zastąpienie porządku symbolicznego porządkiem ego, dziecięca dusza próbuje wyplątać się z życia swej wspólnoty poprzez zanurzenie w tak niepokojąco powszechne stany depresyjne (czy zaburzenia integracji sensorycznej, gdyż właśnie bezpośrednie doświadczenie jest jedynym prawdziwym pokarmem duszy...). Co zatem dziecięca dusza mówi poprzez te zachowania? Można na nie spojrzeć jak na próbę odseparowania się dziecięcej duszy od uczestnictwa w życiu wspólnoty, której jest częścią, a zarazem wskazać na uczestnictwo (sprawczy czynnik) wspólnoty w tym odseparowaniu. Czego zatem pragnie dziecięca dusza i dlaczego zabiera dziecko w takie ciemne i dręczące rejony? Pragnie, aby ktoś zatroszczył się o nią i zdetronizował ego... „Kiedy pojęlibyśmy, że zaangażowanie w relacje ma dla duszy fundamentalne znaczenie, bylibyśmy z definicji w sposób nieunikniony połączeni i zespoleni z innymi przeplatając i scalając pokręcone nici naszego losu z duszami innych" (Hillman 2020: 258-259).

Z racji polifoniczności myśli Hillmana, jej literackiego języka oraz (post)jungowskiej „maniery” wielości i zmienności znaczeń prawie każdej kategorii i idei, w tym duszy czy ego, tekst z konieczności jedynie sygnalizuje spektrum tematyczne i stanowi co najwyżej zaczyn pod dalsze rozważania i pogłębioną analizę relacji ego - wychowanie.

\section{Bibliografia}

Brock A. (red.) (2006) Internationalizing the history of psychology, New York, New York University Press.

Danziger. K. (2002) Constructing the subject. Historical origins of psychological research, Cambridge, Cambridge University Press. 
Danziger K. (2012) Historical psychology of persons: categories and practice w: The psychology of personhood: Philosophical, historical, social-developmental and narrative perspectives, J. Martin, M. H. Bickhard (red.), Cambridge, University Press, s. 59-80.

De Waal F. (2018) Ateista i bonobo. W poszukiwaniu humanizmu wśród naczelnych, tłum. K. Kornas, Kraków, Copernicus Center Press.

Dilthey W. (1982) Pisma estetyczne, tłum. K. Krzemieniowa, Warszawa, PWN.

Dilthey W. (1987) O istocie filozofii oraz inne pisma, tłum. E. Paczkowska-Łagowska, Warszawa, PWN.

Dilthey W. (2004) Budowa świata historycznego w naukach humanistycznych, tłum. E. Paczkowska-Łagowska, Gdańsk, Słowo/obraz terytoria.

Doda-Wyszyńska A. (2020) Mitologia coachingu w: Mity kultury współczesnej. Perspektywa psychoantropologiczna, M. Obrębska, A. Pankalla (red.), Poznań, Wydawnictwo Nauk Społecznych i Humanistycznych UAM, s. 241-256.

Dunbar R. (2019) Człowiek. Biografia, tłum. Ł. Lamża, Kraków, Copernicus Center Press.

Frankfurtczyk (2013) Teologia niemiecka, tłum. P. Augustyniak, Warszawa, Fundacja Augusta hr. Cieszkowskiego.

Geertz C. (2005) Wiedza lokalna. Dalsze eseje z zakresu antropologii interpretatywnej, tłum. D. Wolska, Kraków, Wydawnictwo Uniwersytetu Jagiellońskiego.

Harari Y. N. (2018) Sapiens. Od zwierząt do bogów, tłum. J. Hunia, Kraków, Wydawnictwo Literackie.

Hillman J. (2014) Kod duszy. W poszukiwaniu charakteru człowieka i jego powołania, tłum. J. Korpanty, Warszawa, Laurum.

Hillman J. (2016) Re-wizja psychologii, tłum. J. Korpanty, Warszawa, Laurum.

Hillman J. (2017) Siła charakteru, tłum. J. Korpanty, Warszawa, Laurum.

Hillman J. (2020) Samobójstwo a dusza, tłum. J. Korpanty, Warszawa, Laurum.

Marecek J., Hare-Mustin R. T. (2009) Clinical Psychology: The Politics of Madness w: Critical Psychology: Introduction, D. Fox, I. Prilleltensky, S. Austin (red.), Los Angeles, London, New Delhi, Singapore, Washington DC: Sage, s. 75-92. 
Pankalla A., Kilian A. (2018) Re-wizja i re-autoryzacja psychologii. Ekspedycja na peryferie - od myśli krytycznej ku psychologii realnej, „Czasopismo Psychologiczne” 24 (1), s. 21-35.

Parker I. (1999) Critical psychology: Critical links, "Annual Review of Critical Psychology", 1, s. 3-18.

Sloan A. (2009) Theories of Personality w: Critical Psychology: Introduction, D. Fox, I. Prilleltensky, S. Austin (red.), Los Angeles, London, New Delhi, Singapore, Washington DC: Sage, s. 57-74. 